\title{
CHARACTERIZATION OF Zn-Mg-AI BASED COATING
}

\author{
${ }^{1}$ Petr MOHYLA, ${ }^{1}$ Jiřina VONTOROVÁ, ${ }^{1}$ Karolina SLAMOVÁ \\ ${ }^{1}$ VSB - Technical University of Ostrava, Ostrava, Czech Republic, EU, ïrina.vontorova@vsb.cz
}

https://doi.org/10.37904/metal.2021.4202

\begin{abstract}
This paper aims to characterize $\mathrm{Zn}-\mathrm{Mg}$-Al based coating by profile analysis and determine its thickness as a basic property of the coatings. The most frequently used method for its determination is optical microscopy, but it is time-consuming and destructive. Glow Discharge Optical Emission Spectrometry (GDOES) was chosen as the second method for determining both the thickness and the chemical composition of the coating. The results show that both methods give statistically identical results. The suitability of using GDOES for $\mathrm{Zn}$ layer analysis has already been demonstrated in the literature, and this work confirms these conclusions. Its use for the analysis of alloy layers has been verified by this work.
\end{abstract}

Keywords: Zn-Mg-Al layer, Zn layer, GDOES, optical microscopy

\section{INTRODUCTION}

The basic methods dealing with corrosion protection [1-3] include the hot-dip galvanizing method [4]. Hot-dip galvanized sheets are often used in the automotive industry, where formability is also an important feature [5]. The principle of this method consists in the contact of the iron contained in the steel with zinc [6]. The reaction occurs to form a tightly bonded alloy coating that provides corrosion protection to the steel [7]. Zn coatings have undeniable advantages, but they still corrode due to their higher electrode potential relative to steel. The dissolution rate and the difference in corrosion potential between $\mathrm{Zn}$ and steel can reduce the use of $\mathrm{Zn}$ alloy coating with Ni [8,9], Co [10] or Sn [11]. Currently, Zn-Mg-Al based anti-corrosion coating is being studied [12]. In addition to the increased corrosion resistance, the coatings obtained from these baths have higher hardness and scratch resistance [13].

The elements added to the zinc bath significantly affect the structure, appearance and corrosion resistance of the resulting coating [12]. Aluminium improves the plasticity of the coating, lightens, increases gloss and improves corrosion resistance by forming a zinc coating containing $\mathrm{Al}_{2} \mathrm{O}_{3}$. Fe-Al intermetallic phases are emitted at the solid/liquid interface during the galvanising process, forming a barrier to the reactive diffusion of zinc and preventing the growth of $\mathrm{Fe}-\mathrm{Zn}$ intermetallic phases. Magnesium improves the wettability of the steel substrate, reduces the surface tension of the bath, and improves corrosion resistance.

Glow Discharge Optical Emission Spectrometry (GDOES) [14] is a method used to determine the average chemical composition of the base material [15] as well as the thickness and chemical composition of $\mathrm{Zn}$ layers [16]. In this paper, its use for the analysis of alloy coatings is verified. Optical microscopy is used as a comparative method [17].

\section{EXPERIMENTAL MATERIAL}

The thickness and composition of the $\mathrm{Zn}-\mathrm{Mg}-\mathrm{Al}$ and $\mathrm{Zn}$ layers (galvanized sheet without surface finishing) were characterized on two sheets of non-alloy steel (see Figure 1). The chemical composition of the base material was determined after evaporation of the "BULK" surface layer by Glow Discharge Optical Emission Spectrometry analysis (Table 1). 

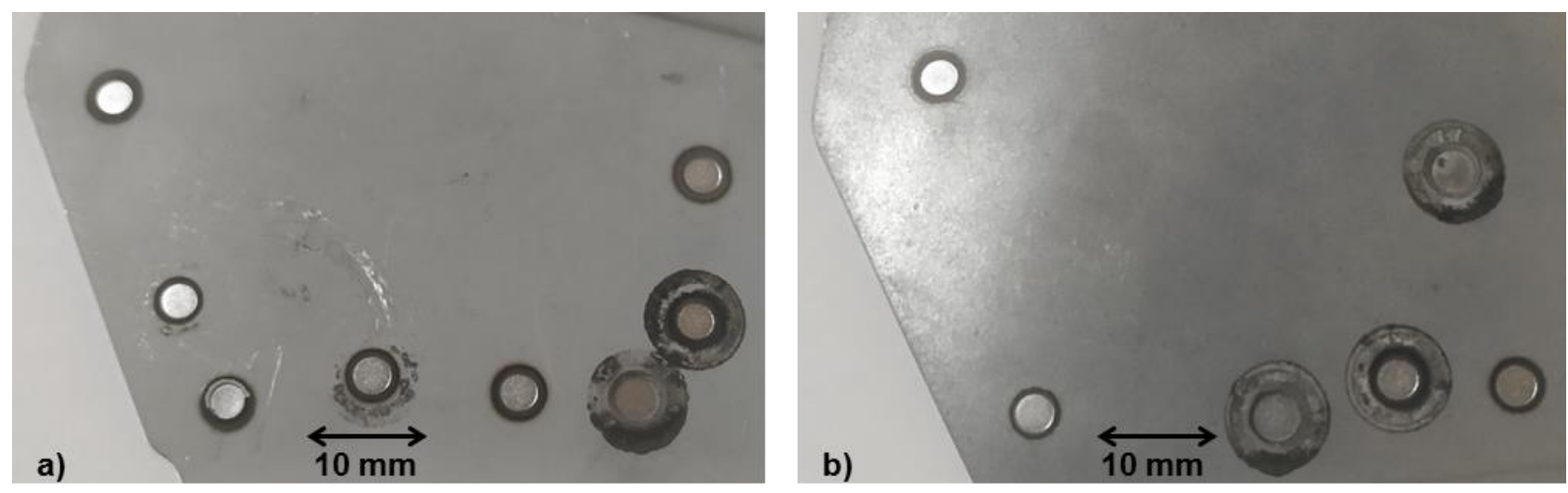

Figure 1 Samples with craters after GDOES profile analysis a) Zn coating, b) Zn-Mg-Al coating

Table 1 Chemical composition of the base material (wt. \%)

\begin{tabular}{|c|c|c|c|c|c|c|c|}
\hline $\mathbf{C}$ & $\mathbf{M n}$ & $\mathbf{S i}$ & $\mathbf{P}$ & $\mathbf{S}$ & $\mathbf{C r}$ & $\mathbf{N i}$ & Mo \\
\hline \multicolumn{7}{|c|}{ wt. \% } & \multicolumn{2}{c|}{} \\
\hline$<0.001$ & 0.128 & $<0.001$ & 0.012 & 0.010 & 0.035 & 0.061 & 0.005 \\
\hline $\mathbf{C u}$ & $\mathbf{T i}$ & $\mathbf{C o}$ & $\mathbf{B}$ & $\mathbf{P b}$ & $\mathbf{V}$ & $\mathbf{W}$ & $\mathbf{A l}$ \\
\hline \multicolumn{7}{|c|}{ wt. \% } \\
\hline 0.051 & 0.032 & $<0.001$ & $<0.001$ & $<0.001$ & 0.010 & $<0.001$ & 0.077 \\
\hline
\end{tabular}

\section{EXPERIMENTAL METHODS}

A glow discharge optical emission spectrometer made by Spectruma Analytik GmbH (model GDA 750) was used in this work. The average chemical composition of the sample base material was determined by BULK GDOES analysis under $700 \mathrm{~V}$ and $35 \mathrm{~mA}$ excitation conditions. Profile analysis was performed under excitation conditions of $1000 \mathrm{~V}$ and $15 \mathrm{~mA}$. Measurement of the zinc layer thickness on the sample was performed in cross-section on an Olympus IX50 optical microscope. Both of these instruments are operated at the Faculty of Materials Science and Technology, VSB - Technical University of Ostrava.

\section{RESULTS AND DISCUSSION}

In the following figure (Figure 2), two records of profile GDOES analysis of galvanized sheet and Zn-Mg-Al coated sheet are shown as an example. As expected, >99\% zinc was measured on the surface of the $\mathrm{Zn}$ sheet (Figure 2a), with the proportion of zinc decreasing with increasing crater depth and the proportion of iron and other elements that were part of the base material increasing. The other elements have such low percentages that it would be meaningless to show them. Even the scales of the profile records of magnesium, aluminium, manganese, chromium, nickel and copper had to be changed for the sake of recognition - the value subtracted from the record must be divided by the constant given in the legend of the records.

In the profile analysis record of the $\mathrm{Zn}-\mathrm{Mg}$-Al coated sheet (Figure 2b), the concentration of $\mathrm{Zn}$, magnesium and aluminium is approximately $95 \%, 3.7 \%$ and $0.7 \%$, respectively; their concentration decreased with crater depth. The concentration of iron and other elements contained in the base material increased analogously with decreasing Zn coating.

The curve of zinc content in the base material varied for both the conventional and modified coating. This may have been due to a non-stabilised detector or the analyser sensitivity to the dusty material redeposited on the crater wall. 

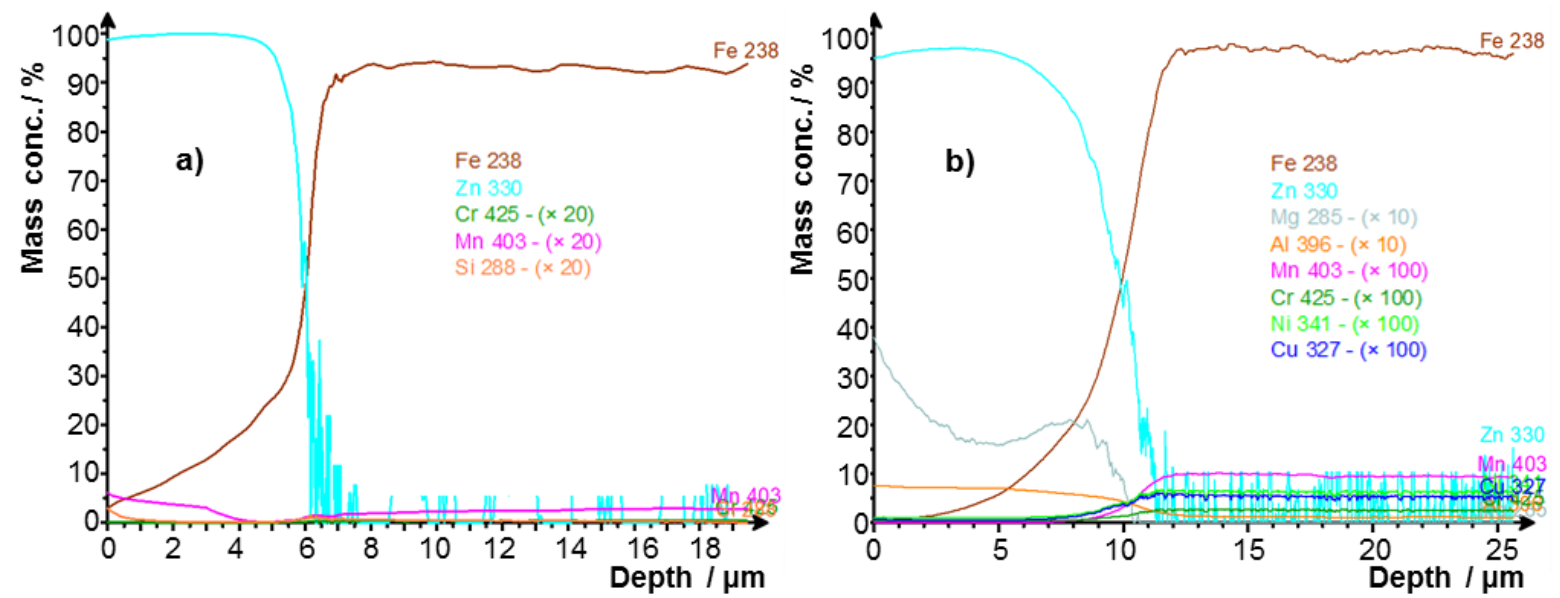

Figure 2 Profile records of GDOES analyses of non-alloy steel sheet with a) Zn coating, b) Zn-Mg-Al coating

As shown in (Figure 1), the records were measured repeatedly. The individual thicknesses were not statistically different and are recorded in Table 2 . The average thickness of the $\mathrm{Zn}$ coating was $10.1 \mu \mathrm{m}$, and that of the $\mathrm{Zn}-\mathrm{Mg}-\mathrm{Al}$ coating was $6.0 \mu \mathrm{m}$. The coating thickness was read at the point where the $\mathrm{Zn}$ and Fe profile curves crossed.

Table 2 Surface layer thicknesses determined by GDOES $(\mu \mathrm{m})$

\begin{tabular}{|c|c|c|}
\hline \multirow{2}{*}{ Sample } & Zn coating & Zn-Mg-Al coating \\
\cline { 2 - 3 } & \multicolumn{2}{|c|}{$\boldsymbol{\mu m}$} \\
\hline Measurement 1 & 6.1 & 10.1 \\
\hline Measurement 2 & 5.7 & 10.2 \\
\hline Measurement 3 & 6.2 & 10.1 \\
\hline Measurement 4 & 6.1 & 10.0 \\
\hline Measurement 5 & 6.0 & 10.3 \\
\hline Average & $\mathbf{6 . 0}$ & $\mathbf{1 0 . 1}$ \\
\hline
\end{tabular}

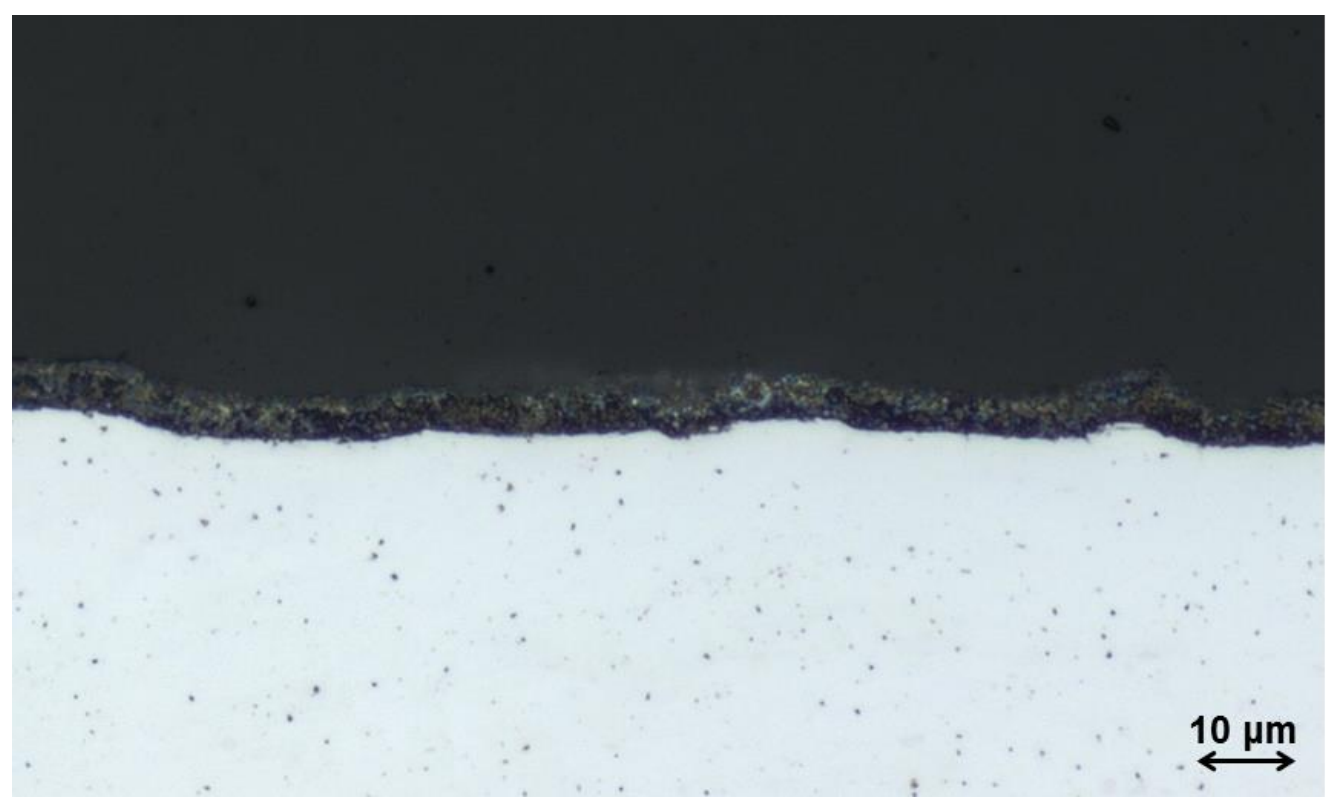

Figure $3 \mathrm{Zn}$ coating - cross-section on Olympus IX70 optical microscope 
Optical microscopy was chosen as the method of comparison. The samples were subjected to metallographic preparation before analysis and then observed on an optical microscope. Two samples of each type of coated sheet were prepared, and the thickness and uniformity of the coatings were assessed.

The following figures show cross-sectional images of the samples obtained using an Olympus IX70 optical microscope (Figures 3 and 4). The Zn-Mg-Al coated image (Figure 4) shows the eutectic microstructure of the coating. The classical $\mathrm{Zn}$ coating is characterized by a homogeneous microstructure (Figure 3).

Coating thicknesses were measured at 10 locations in each image (as shown in Figure 4). The galvanic $\mathrm{Zn}$ coating reached an average thickness of $5.8 \mu \mathrm{m}$ on the first sample and $5.3 \mu \mathrm{m}$ on the second sample. The average thickness of the $\mathrm{Zn}-\mathrm{Mg}-\mathrm{Al}$ coating was $10.2 \mu \mathrm{m}$ (sample 1) and $11.1 \mu \mathrm{m}$ (sample 2). All measured values are shown in Table 3. The measured values (20 for each type of coating) were statistically evaluated by QC Expert software and were found to have a Gaussian distribution with no outliers. Box plots confirming these conclusions are shown in (Figure 5).

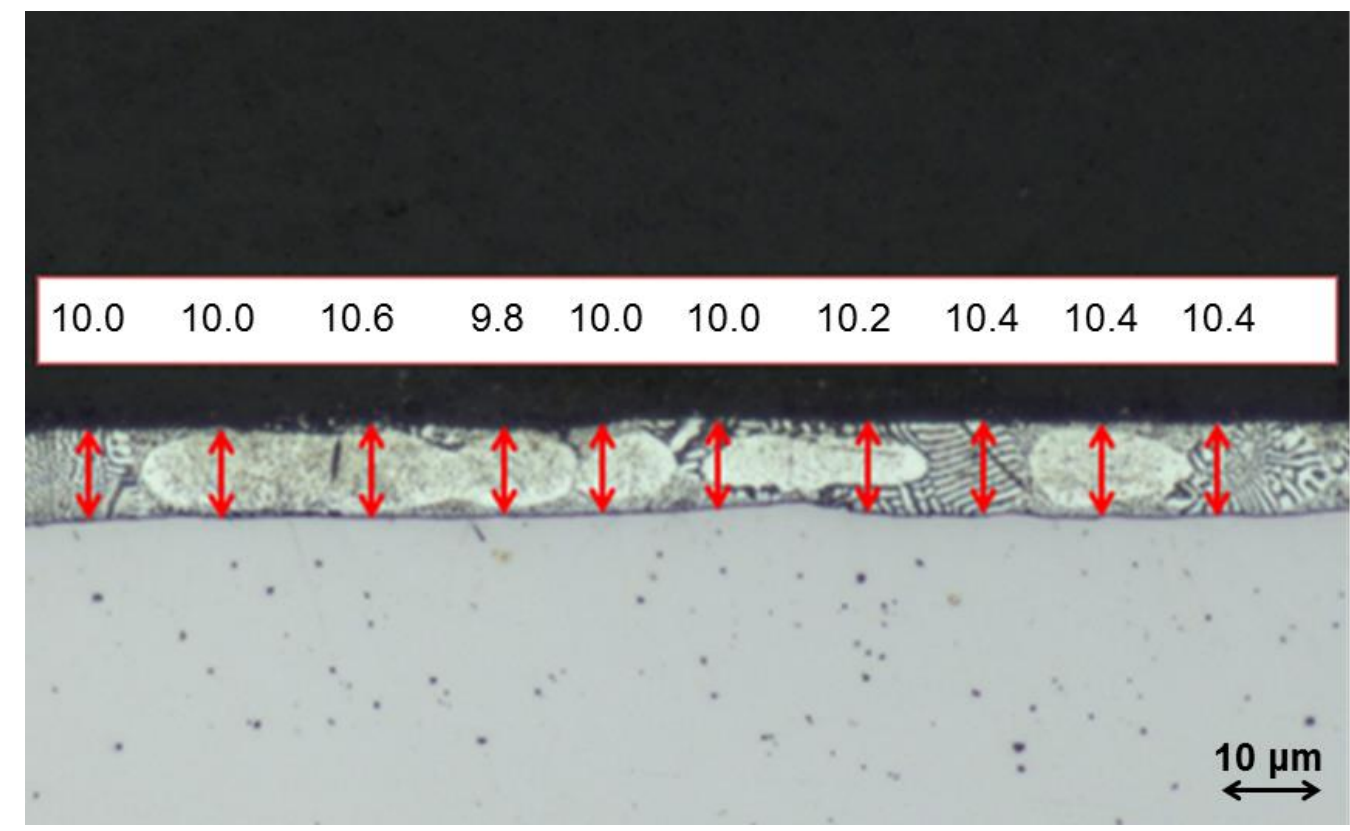

Figure 4 Zn-Mg-Al coating - in cross-section on Olympus IX70 optical microscope - with layer thickness measurement

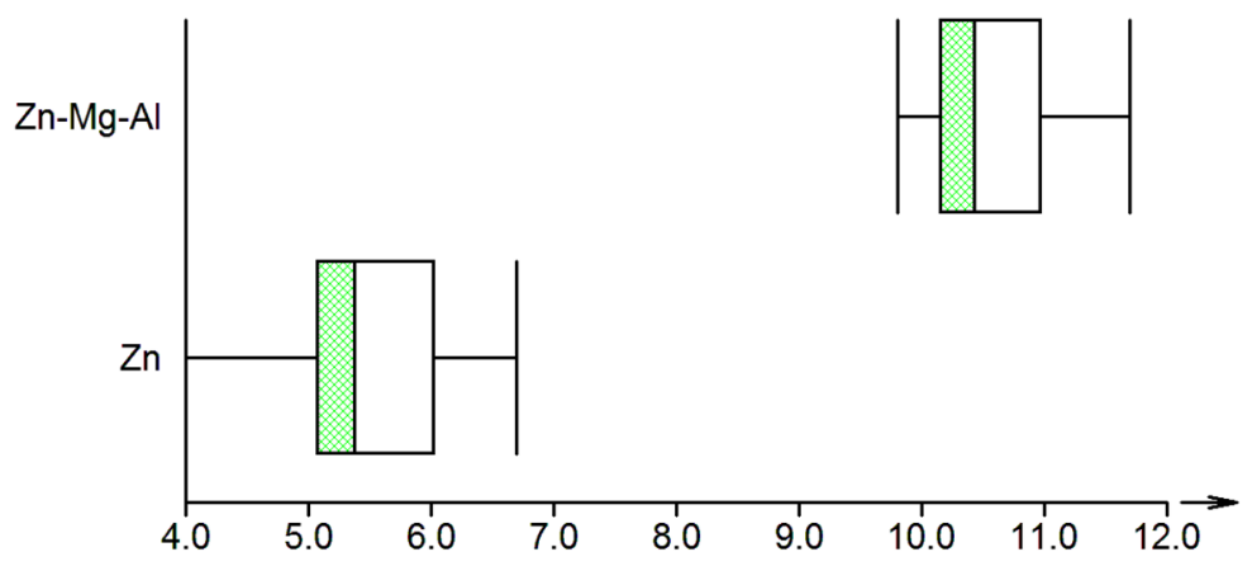

Figure 5 Box plots - evaluation of layer thicknesses of Zn and Zn-Mg-Al coatings - QC Expert software 
Table 3 Surface layer thicknesses determined by optical microscopy $(\mu \mathrm{m})$

\begin{tabular}{|c|c|c|c|c|}
\hline \multirow{3}{*}{ Sample } & \multicolumn{2}{|c|}{ Zn coating } & \multicolumn{2}{|c|}{ Zn-Mg-Al coating } \\
\hline & model 1 & model 2 & model 1 & model 2 \\
\hline & \multicolumn{4}{|c|}{$\mu \mathrm{m}$} \\
\hline Measurement 1 & 5.8 & 5.0 & 10.0 & 11.7 \\
\hline Measurement 2 & 5.7 & 6.5 & 10.0 & 10.9 \\
\hline Measurement 3 & 5.8 & 4.6 & 10.6 & 11.3 \\
\hline Measurement 4 & 5.6 & 5.1 & 9.8 & 10.9 \\
\hline Measurement 5 & 6.2 & 5.0 & 10.0 & 10.9 \\
\hline Measurement 6 & 5.6 & 5.5 & 10.0 & 11.1 \\
\hline Measurement 7 & 5.7 & 4.0 & 10.2 & 10.9 \\
\hline Measurement 8 & 5.8 & 4.2 & 10.4 & 11.1 \\
\hline Measurement 9 & 6.1 & 6.0 & 10.4 & 10.8 \\
\hline Measurement 10 & 6.0 & 6.7 & 10.4 & 11.0 \\
\hline diameter & 5.8 & 5.3 & 10.2 & 11.1 \\
\hline
\end{tabular}

The following table (Table 4) summarises the results obtained - i.e. compares the thicknesses of the individual layers determined by the two methods.

Table 4 Comparison of results (surface layer thicknesses) determined by GDOES and optical microscopy $(\mu \mathrm{m})$

\begin{tabular}{|c|c|c|}
\hline \multirow{2}{*}{ Sample } & \multicolumn{2}{|c|}{ Average layer thickness } \\
\cline { 2 - 3 } & Optical microscopy & GDOES \\
\cline { 2 - 3 } & & \multicolumn{2}{|c|}{$\boldsymbol{| c}$} \\
\hline Zn coating & 5.5 & 6.0 \\
\hline Zn-Mg-Al coating & 10.6 & 10.1 \\
\hline
\end{tabular}

\section{CONCLUSION}

This work aimed to characterize the $\mathrm{Zn}-\mathrm{Mg}-\mathrm{Al}$ coating using optical microscopy and GDOES analysis and compare it with the classical galvanic zinc coating. It was found that the thickness of the Zn-Mg-Al surface layer is larger (almost twice) and more even than that of the pure galvanic zinc layer. Furthermore, the suitability of using GDOES analysis to analyse alloy coatings was confirmed.

\section{ACKNOWLEDGEMENTS}

This work was solved within the frame of project No. SS01020312 "Innovative technology of the closed loop water circulation in the electro-galvanizing process and processing of metal waste sludges and filtration cakes from the galvanizing plant" and was supported by VŠB-Technical University of Ostrava by project No. SP2021/104.

\section{REFERENCES}

[1] PODJUKLOVÁ, J., SUCHÁNKOVÁ, K., ŠRUBAR, P., KOPANAKOVÁ, S., HRABOVSKÁ, K. Study of influence corrosive environment on characteristics protective coatings used for long-term corrosion protection of steel 
substrate. In: METAL 2013: 22nd International Conference on Metallurgy and Materials. Ostrava: TANGER, 2013, pp. 953-958. WOS: 000333163100156

[2] PODJUKLOVÁ, J.: Speciální technologie povrchových úprav I. Učební texty. VŠB - TUO, Ostrava, 1997, 71 p. ISBN 80-8778-235-8.

[3] YEGANEH, M., NGUYEN, T.A. Methods for Corrosion Protection of Metals at the Nanoscale. Kenkyu J. Nanotechnol. Nanosci. May 2019, vol. 5, pp. 37-44. Available from: https://doi.org/10.31872/2019/KJNN-100123.

[4] VONTOROVÁ, J., MOHYLA, P. Use of GDOES method for evaluation of the quality and thickness of hot dip galvanised coating. Transactions of the Institute of Metal Finishing. 2018, vol. 96, no. 6, pp. 313-318. Available from: https://doi.org/10.1080/00202967.2018.1520531.

[5] ČADA, R. Formability of deep-drawing steel sheets. In: Proceedings of the 5th European Conference on Advanced Materials and Processes and Applications (EUROMAT 97): Materials, Functionality \& Design:

Volume 4 - Characterization and Production/Design. Maastricht: Netherlands Society for Materials Science, 1997, pp. 463-466. ISBN 90-803513-4-2. WOS: A1997BJ43P00097.

[6] BROŽOVÁ, S., DRÁPALA, J., KURSA, M., PUSTĚJOVSKÁ, P., JURSOVÁ, S. Leaching refuse after sphalerite mineral for extraction zinc and cobalt. Metalurgija. 2016, vol. 55, Issue 3, pp. 497-499. WOS:000372344500054

[7] KUKLÍK, V., KUDLÁČEK, J. Hot-Dip galvanizing of steel structures. Elsevier Inc., 2016.

[8] OZGA, P., BIELAŃSKA, E. Determination of the corrosion rate of $\mathrm{Zn}$ and $\mathrm{Zn}$-Ni layers by the EDS technique. Materials Chemistry and Physics. 2003, vol. 81, no. 2-3, pp. 562-565. Available from:

https://doi.org/10.1016/S0254-0584(03)00075-0.

[9] BYK, T. V., GAEVSKAYA, T.V., TSYBULSKAYA, L.S. Effect of electrodeposition conditions on the composition, microstructure, and corrosion resistance of Zn-Ni alloy coatings. Surface and Coatings Technology. 2008, vol. 202, no. 24, pp. 5817-5823. Available from: https://doi.org/10.1016/..surfcoat.2008.05.058.

[10] ABOU-KRISHA, M.M. Influence of Ni2+ concentration and deposition potential on the characterization of thin electrodeposited Zn-Ni-Co coatings. Materials Chemistry and Physics. 2011, vol. 125, no. 3, pp. 621-627. Available from: https://doi.org/10.1016/j.matchemphys.2010.10.007.

[11] DUBENT, S., MERTENS, M.L.A.D., SAURAT, M. Electrodeposition, characterization and corrosion behaviour of tin-20 wt.\% zinc coatings electroplated from a non-cyanide alkaline bath. Materials Chemistry and Physics. 2010, vol. 120, no. 2-3, pp. 371-380. Available from: https://doi.org/10.1016/i.matchemphys.2009.11.017.

[12] KLIMEK, L., WAŚ-SOLIPIWO, J., DYBOWSKI, K.. Effect of Aluminium and Magnesium on the Corrosion Resistance of Zinc Coatings. Advances in Science and Technology Research Journal. 2017, vol. 11, no. 2, pp. 28-32. Available from: https://doi.org/10.12913/22998624/67675.

[13] DUTTA, M., HALDER, A.K., SINGH, S.B. Morphology and properties of hot dip Zn-Mg and Zn-Mg-Al alloy coatings on steel sheet. Surface and Coatings Technology. 2010, vol. 205, no. 7, pp. 2578-2584. Available from: https://doi.org/10.1016/i.surfcoat.2010.10.006.

[14] ESCOBAR GALINDO, R., FORNIÉS, E., ALBELLA, J.M. Compositional depth profiling analysis of thin and ultrathin multilayer coatings by radio-frequency glow discharge optical emission spectroscopy. Surface and Coatings Technology. 2006, vol. 200, no. 22-23, pp. 6185-6189. Available from: https://doi.org/10.1016/j.surfcoat.2005.11.064.

[15] VONTOROVÁ, J., VÁÑOVÁ, P. Determination of carburized layer thickness by GDOES method, AIMS Materials Science. 2018, vol. 5, no. 1, pp. 34-43. Available from: https://doi.org/10.3934/matersci.2018.1.34.

[16] VONTOROVÁ, J., MOHYLA, P., ŠEVČíKOVÁ, X. Influence of CMT and MIG soldering on zinc layer thickness. In: METAL 2012 - Conference Proceedings, 21st International Conference on Metallurgy and Materials. Brno, Tanger, 2012. WOS:000318506500171

[17] JONŠTA, P., VÁŇOVÁ, P., BROŽOVÁ, S., PUSTĚJOVSKÁ, P. Hydrogen embrittlement of welded joint made of supermartensitic stainless steel in environment containing sulfane. Archives of Metallurgy and Materials. 2016, vol. 61, issue 2A, pp. 709-711. Available from: https://doi.org/10.1515/amm-2016-0121. 